The Economics of

Religion in India

Ge $\infty$ 



\section{The Economics of Religion in India}

$\sigma \curvearrowright$ Sriya Iyer

THE BELKNAP PRESS OF HARVARD UNIVERSITY PRESS

Cambridge, Massachusetts London, England 2018 
Copyright (C) 2018 by the President and Fellows of Harvard College

ALL RIGHTS RESERVED

Printed in the United States of America

First Printing

Library of Congress Cataloging-in-Publication Data

Names: Iyer, Sriya, author.

Title: The economics of religion in India / Sriya Iyer.

Description: Cambridge, Massachusetts : The Belknap Press of Harvard University Press, 2018. |

Includes bibliographical references and index.

Identifiers: LCCN 2018002799 | ISBN 9780674979642 (alk. paper)

Subjects: LCSH: India-Religion-Economic aspects. | Religion and sociology-India. |

Social conflict-India-Religious aspects.

Classification: LCC HB72.I945 2018 | DDC 200.954-dc23

LC record available at https://lccn.loc.gov/2018002799

Cover design: Graciela Galup

Cover art: powerofforever/iStock / Getty Images Plus 